\title{
PENGARUH AKTIVITAS BERMAIN DAN PERSEPTUAL MOTORIK TERHADAP KETERAMPILAN MOTORIK SISWA SEKOLAH DASAR KELAS BAWAH
}

\section{THE INFLUENCE OF PLAYING ACTIVITY AND PERCEPTUAL MOTOR ABILITY ON MOTOR SKILLS AMONG LOWER GRADE ELEMENTARY SCHOOL STUDENTS}

\author{
Gustiana Mega Anggita, Hari Amirullah Rachman \\ Prodi Ilmu Keolahragaan PPs UNY, Universitas Negeri Yogyakarta \\ mega.anggita22@yahoo.com, harirachman@yahoo.com.au
}

\begin{abstract}
Abstrak
Penelitian ini bertujuan untuk mengetahui pengaruh aktivitas bermain dan perseptual motorik terhadap keterampilan motorik siswa sekolah dasar kelas bawah. Penelitian ini adalah penelitian eksperimen menggunakan rancangan faktorial 2 x 2 dengan menggunakan tes awal dan tes akhir. Data dikumpulkan menggunakan tes dan pengukuran, menggunakan instrument general motor ability test dan tes kemampuan perseptual motorik. Analisis data menggunakan ANAVA dua jalan dan uji Tukey. Hasil penelitian menunjukkan sebagai berikut, (1) aktivitas bermain dengan alat memiliki pengaruh lebih besar dibandingkan aktivitas bermain tanpa alat terhadap keterampilan motorik. (2) Terdapat perbedaan antara model aktivitas bermain dengan alat dan model aktivitas bermain tanpa alat pada kelompok kemampuan perseptual motorik tinggi terhadap keterampilan motorik. (3) Tidak terdapat perbedaan antara model aktivitas bermain dengan alat dan model aktivitas bermain tanpa alat pada kelompok dengan kemampuan perseptual motorik rendah terhadap keterampilan motorik. (4) Terjadi interaksi antara model aktivitas bermain dan kemampuan perseptual motorik terhadap keterampilan motorik.
\end{abstract}

Kata kunci: aktivitas bermain, kemampuan perseptual motorik, keterampilan motorik.

\begin{abstract}
This research aimed to determine the influence of playing activity and perceptual motor ability on motor skills among lower grade elementary school students. This research is an experimental research using a $2 \times 2$ factorial design with initial test and final test. The data were collected by means of tests and measurement, using the general motor ability instrument and perceptual motor ability test. Analysis of the data was done using two-way ANOVA and Tukey's test. The results of this study are as follows. (1) the activity models playing with tools have a greater influence than the activity playing without tools for motor skills. (2) There is a difference between activity models playing with tools and activity models playing without tools in the group with high perceptual motor abilities on motor skills. (3) There is no difference between activity models playing with tools and activity models playing without tools in the group with low perceptual motor abilities on motor skills. (4) There was an interaction between activity models playing with tools and activity models playing without tools and perceptual motor abilities towards motor skills.
\end{abstract}

Keywords: playing activity, perceptual motor ability, motor skills. 


\section{Pendahuluan}

Menurut UU No. 20 tahun 2003 tentang Sistem Pendidikan Nasional, pendidikan adalah usaha sadar terencana untuk mewujudkan suasana belajar dan proses pembelajaran agar peserta didik secara aktif mengembangkan potensi dirinya untuk memiliki kekuatan spiritual keagamaan, pengendalian diri, kepribadian, kecerdasan, akhlak mulia, serta keterampilan yang diperlukan darinya, masyarakat, bangsa, dan negara, (Hartoto, 2009). Pendidikan jasmani pada dasarnya merupakan bagian integral dari sistem pendidikan secara keseluruhan. Tujuan pendidikan jasmani bukan hanya mengembangkan ranah jasmani, tetapi juga mengembangkan aspek kesehatan, kebugaran jasmani, keterampilan berfikir kritis, stabilitas emosional, keterampilan sosial, penalaran dan tindakan moral melalui kegiatan aktivitas jasmani dan olahraga. Perkembangan jasmani anak tidak semata-mata bergantung pada proses kematangan. Perkembangan itu juga dipengaruhi oleh pengalaman gerak anak baik ditinjau dari aspek mutu maupun banyaknya pengalaman itu (Lutan, 2001, p.17). Anak harus memperoleh kesempatan yang banyak untuk bergerak dan bermain. Oleh karena itu, peranan pendidikan jasmani dirasakan sangat penting untuk memberikan pengalaman gerak yang dapat menunjang pertumbuhan dan perkembangan anak baik perkembangan psikomotor, kognitif maupun afektif. Pada umumnya proses pembelajaran penjas di sekolah dasar diberikan melalui model-model permainan atau dengan kata lain pembelajaran penjas di sekolah dasar dilakukan dengan bermain karena melalui permainan proses pembelajaran menjadi menyenangkan dan anak-anak pun akan melakukan aktivitas dengan senang sehingga pembelajaran dapat berjalan efektif dan efisien.

Bermain dalam proses pembelajaran dapat memberikan berbagai pengalaman gerak bagi anak, dimana pengalaman gerak tersebut sangat berperan dalam proses pertumbuhan dan perkembangan anak. Perkembangan gerak bagi anak-anak SD diartikan sebagai perkembangan dan penghalusan aneka keterampilan gerak dasar dan keterampilan gerak yang berkaitan dengan olahraga. Keterampilan gerak yang berkaitan dengan olahraga inilah yang disebut dengan keterampilan motorik. Keterampilan motorik merupakan sebuah proses dimana seseorang mengembangkan seperangkat respon ke dalam suatu pola gerak yang terkoordinasi, ter- organisasi dan terpadu (Lutan, 2001, p.21). Dalam konsep Bloom, dinyatakan bahwa terdapat pemilahan dalam aspek keterampilan motorik (Ranah Psikomotorik), salah satunya yaitu perseptual motorik yang mencakup kemampuan untuk mengadakan diskriminasi yang tepat antara dua perangsang atau lebih, berdasarkan perbedaan antara ciri-ciri fisik yang khas pada masing-masing rangsangan. Kemampuan ini dinyatakan dalam suatu reaksi yang menunjukkan kesadaran akan hadirnya rangsangan (stimulasi) dan perbedaan antara rangsangan-rangsangan yang ada, (Qomariyah, 2009). Sejumlah pengalaman belajar dalam pendidikan jasmani disediakan dengan tujuan untuk memupuk kemampuan perseptual motorik. Perseptual motorik menunjuk kepada proses gerak yang dihasilkan melalui penerimaan dan pemilahan rangsang. Proses penerimaan dan seleksi rangsang, hingga menghasilkan jawaban berupa gerak yang disebut persepsi gerak (perseptual motorik). Proses pemberian tugas gerak ini melibatkan fungsi saraf dan sel-sel saraf dalam otak sehingga rangsangan dari pemberian tugas gerak diarahkan untuk mengembangkan kecerdasan seseorang dimana pemberian rangsang atau tugas gerak itu membuat anak menjawab tiga persoalan yaitu mengapa, apa, bagaimana dan kapan tugas gerak dilaksanakan.

Berdasarkan observasi yang dilakukan terhadap guru penjas di SD Percobaan 2 dan SDIT Ar-Raihan salah satu permasalahan dalam pembelajaran penjas yaitu materi-materi pembelajaran, terkadang para guru merasa bingung memberikan materi pembelajaran seperti apa khususnya untuk siswa sekolah dasar kelas bawah. Sedangkan pada pembahasan sebelumnya telah dikemukakan bahwa pembelajaran penjas di sekolah dasar memiliki peranan penting untuk pertumbuhan dan perkembangan anak khususnya perkembangan gerak anak. Selama ini belum ada data yang mengemukakan tentang tingkat keterampilan motorik ditinjau dari kemampuan perseptual motorik dan jenis aktivitas jasmani yang dilakukan anak padahal data tersebut sangat penting sebagai dasar penyusunan program pendidikan jasmani bagi siswa sekolah dasar khususnya siswa kelas bawah, seperti dikemukakan oleh para pakar penjas di atas. Berdasarkan uraian tersebut, penulis bermaksud melakukan penelitian pengaruh aktivitas bermain dan perseptual motorik terhadap keterampilan motorik siswa sekolah dasar kelas bawah.

Dari latar belakang masalah yang telah kemukakan sebelumnya, permasalahan yang 
dapat dirumuskan antara lain: (1) Apakah terdapat perbedaan keterampilan motorik pada siswa sekolah dasar kelas bawah sebagai pengaruh penggunaan model aktivitas bermain dengan alat (model A) dan model aktivitas bermain tanpa alat (model B). (2) Apakah terdapat perbedaan keterampilan motorik pada siswa sekolah dasar kelas bawah dengan kemampuan perseptual motorik tinggi sebagai pengaruh penggunaan model aktivitas bermain dengan alat (model A) dengan model aktivitas bermain tanpa alat (model B). (3) Apakah terdapat perbedaan keterampilan motorik pada siswa sekolah dasar kelas bawah dengan kemampuan perseptual motorik rendah sebagai pengaruh penggunaan model aktivitas bermain dengan alat (model A) dan model aktivits bermain tanpa alat (model B). (4) Apakah terdapat interaksi antara aktivitas bermain dan perseptual motorik terhadap keterampilan motorik siswa sekolah dasar kelas bawah. Sesuai dengan rumusan masalah di atas, tujuan yang ingin dicapai dalam penelitian ini adalah adalah sebagai berikut: (1) Mengetahui apakah terdapat perbedaan keterampilan motorik pada siswa sekolah dasar kelas bawah sebagai pengaruh penggunaan model aktivitas bermain dengan alat (model A) dan model aktivitas bermain tanpa alat (model B). (2) Mengetahui apakah terdapat perbedaan keterampilan motorik pada siswa sekolah dasar kelas bawah dengan kemampuan perseptual motorik tinggi sebagai pengaruh penggunaan model aktivitas bermain dengan alat (model A) dengan model aktivitas bermain tanpa alat (model B). (3) Mengetahui apakah terdapat perbedaan keterampilan motorik pada siswa sekolah dasar kelas bawah dengan kemampuan perseptual motorik rendah sebagai pengaruh penggunaan model aktivitas bermain dengan alat (model A) dan model aktivits bermain tanpa alat (model B). (4) Mengetahui apakah terdapat pengaruh interaksi antara aktivitas bermain dan perseptual motorik terhadap keterampilan motorik siswa sekolah dasar kelas bawah. Manfaat dari penelitian ini antara lain: (1) Guru Penjas Sekolah Dasar (SD) khususnya kelas bawah, penelitian ini dapat digunakan sebagai data untuk mengetahui pengaruh aktivitas bermain dan perseptual motorik terhadap keterampilan motorik siswa sekolah dasar kelas bawah. (2) Bagi Kepala Sekolah, hasil penelitian ini diharapkan dapat memberikan masukan bagi pengembangan pembelajaran pendidikan jasmani di sekolah. (3) Bagi Orang tua penelitian ini diharapkan dapat memberikan wawasan tentang pentingnya aktivitas bermain dan perseptual motorik bagi pertumbuhan dan perkembangan anak khususnya perkembangan keterampilan gerak anak.

\section{Metode Penelitian}

Jenis Penelitian

Jenis penelitian dalam penelitian ini adalah penelitian eksperimen.

\section{Waktu dan Tempat Penelitian}

Penelitian ini dilakukan di SD Percobaan 2 Sleman Yogyakarta dan SDIT Arraihan Bantul Yogyakarta. Waktu pelaksanaan penelitian yaitu berlangsung pada tanggal 11 Maret9 Juni 2013. Objek penelitian difokuskan pada siswa sekolah dasar kelas bawah.

\section{Target/Subjek Penelitian}

Dalam penelitian ini, peneliti menggunakan teknik pengambilan sampel dengan teknik random sampling yaitu teknik yang digunakan apabila populasi dari mana sampel diambil merupakan populasi homogen yang hanya mengandung satu ciri (Arikunto, 2007, p.95). Berdasarkan pendapat tersebut maka dalam penelitian ini penulis mengambil populasi sebanyak 62 siswa. Sebelum eksperimen dilaksanakan, populasi sebanyak 62 siswa, kemudian dilakukan tes dan pengukuran kemampuan perseptual motorik diperoleh dengan tes kemampuan perseptual motorik. Tes ini digunakan untuk mengetahui skor awal yang menunjukkan tingkat kemampuan perseptual motorik.

Tiga langkah untuk menganalisis adalah sebagai berikut: (a) mengatur tes dalam rangka menentukan skor tinggi dan skor rendah, (b) menentukan $27 \%$ skor tinggi dan $27 \%$ skor rendah dengan menempatkan dalam satu kelompok yang sama. Kelompok-kelompok ini disebut kelompok atas dan bawah. Meskipun 27\% kelompok atas dan bawah dianggap yang terbaik untuk memaksimalkan perbedaan antara dua kelompok, atau menggunakan setiap presentasinya antara $25 \%$ sampai $33 \%$, (c) perhitungan jumlah waktu respon yang benar untuk setiap terpilih pada tes masing-masing kelompok (Miller, 2002, p.68). Kemudian tiap kelompok tinggi dan rendah dibagi masingmasing dua kelompok metode aktivitas bermain dengan alat dan aktivitas bermain tanpa alat, sampel yang memiliki kemampuan perseptual motorik tinggi dan sampel yang memiliki kemampuan perseptual motorik rendah dengan cara diundi (random) sehingga akan menjadi 
empat kelompok sesuai dengan kebutuhan penelitian, sehingga setiap sel terisi oleh 7 anak.

Prosedur

Metode penelitian yang digunakan dalam penelitian ini adalah menggunakan rancangan faktorial 2 x 2 yaitu suatu eksperimen faktorial yang menyangkut dua faktor masingmasing faktor terdiri atas dua buah taraf, dengan menggunakan tes awal (pretest) dan tes akhir (posttest). Eksperimen faktorial adalah eksperimen yang hampir atau semua taraf sebuah faktor dikombinasikan atau disilangkan dengan semua taraf tiap faktor lainnya yang ada dalam eksperimen (Sudjana, 2002, p.148). Kerangka desain penelitian dapat dilihat pada tabel 1 . berikut.

Tabel 1. Kerangka Desain Penelitian

\begin{tabular}{ccc}
\hline \multirow{2}{*}{ Variabel Manipulatif Variabel Atributif } & \multicolumn{2}{c}{ Model Pembelajaran } \\
\cline { 2 - 3 } & $\begin{array}{c}\text { Aktivitas Bermain } \\
\text { dengan Alat }\left(\mathbf{A}_{\mathbf{1}}\right)\end{array}$ & $\begin{array}{c}\text { Aktivitas Bermain tanpa } \\
\text { Alat }\left(\mathbf{A}_{2}\right)\end{array}$ \\
\hline Kemampuan Perseptual Motorik Tinggi $\left(\mathbf{B}_{1}\right)$ & $\mathrm{A}_{1} \mathrm{~B}_{1}$ & $\mathrm{~A}_{2} \mathrm{~B}_{1}$ \\
Kemampuan Perseptual Motorik Rendah $\left(\mathbf{B}_{2}\right)$ & $\mathrm{A}_{1} \mathrm{~B}_{2}$ & $\mathrm{~A}_{2} \mathrm{~B}_{2}$ \\
\hline
\end{tabular}

Data, Intrumen, dan Teknik Pengumpulan Data

Teknik pengumpulan data dengan tes awal (pretest) dan tes akhir (posttest). Sesuai dengan variabel, untuk mengambil data penelitian instrumen pengumpulan data yang digunakan adalah:

\section{Data Kemampuan Perseptual Motorik}

Instrumen tes perseptual motorik ini terdiri dari sepuluh tugas gerak (Bullus dan Coles, 2007, p.131). Adapun tugas gerak tersebut adalah (a) Berjalan maju di sepanjang balok selebar $10 \mathrm{~cm}$; (b) Berjalan mundur di sepanjang balok selebar $10 \mathrm{~cm}$; (c) Berjalan menyamping di sepanjang balok selebar $10 \mathrm{~cm}$; (d) Melompat setidaknya 10 langkah; (e) Meloncat dengan kedua kaki sebanyak 5 kali; (f) Melompat dengan satu kaki (anak memilih kaki yang digunakan); (g) Berdiri di atas satu kaki selama minimal 10 detik (perhatikan kaki yang disukai); (h) Berdiri di atas kaki yang lain selama 10 detik; (i) Melempar bola yang berdiameter $14 \mathrm{~cm}$ (perhatikan tangan yang disukai); (j) Menangkap bola yang berdiameter $14 \mathrm{~cm}$ (perhatikan tangan mana yang digunakan atau kedua tangan yang digunakan)

Dalam melaksanakan pengamatan atau observasi terhadap tugas gerak yang dilakukan, perlu dipertimbangkan bagaimana tugas tersebut dilakukan, apakah dilakukan dengan baik dan benar? Apakah dapat mengontrol keseimbangan tubuhnya? Apakah dilakukan dengan rileks? dan lain sebagainya. Untuk itu diperlukan suatu kriteria yang memudahkan observer untuk melakukan pengukuran. Pengukuran dilakukan dengan memberikan angka pada setiap tugas gerak yang dilakukan dengan kriteria sebagai berikut: (1) Skor 3, apabila tugas gerak dilakukan dengan benar tanpa ada kesalahan; (2) Skor 2, apabila tugas gerak dilakukan dengan benar, tidak dengan rileks (kehilangan keseimbangan); (3) Skor 1, apabila tugas gerak hanya dilakukan sebagian saja; (4) Skor 0, apabila tidak mampu melakukan tugas gerak.

\section{Keterampilan Motorik}

Instrumen yang digunakan peneliti untuk mengukur keterampilan motorik yaitu General motor ability test. General motor ability test antara lain:

Pertama,Stork Stand. Berdiri di atas kaki pilihan testi, telapak kaki dikaitkan pada bagian belakang lutut dari kaki pilihan testi. Letakkan tangan diatas pinggul dan angkat dada kaki (jinjit). Skor tes adalah jumlah waktu testi dapat menahan posisi dengan baik.

Kedua, Diver's Stand. Berdiri dengan kedua kaki dan kedua lengan diluruskan ke depan $\left(90^{\circ}\right.$ dengan bahu). Tutup mata dan angkat dada kaki (jinjit). Skor tes adalah jumlah waktu testi dapat menahan posisi dengan baik.

Ketiga, Heel Stand. Bersiap pada posisi dengan kaki dibuka selebar bahu. Bungkukkan badan sedikit sampai tangan berada pada lutut. Jaga kepala agar tetap di atas dan tekan ke belakang tumit sehingga jari-jari kaki tidak menyentuh tanah. Skor tes adalah jumlah waktu testi dapat menahan posisi dengan baik.

Keempat, Sideward Leap. Gunakan pita untuk menandai dua tempat di lantai sekitar 1 meter terpisah. Seimbangkan kaki di atas pita kiri. Melompat ke samping untuk tanda lain, mendarat dengan kaki kanan. Seimbangkan 
untuk 2 hitungan dan kemudian membungkuk untuk menyentuh bagian luar pergelangan kaki dengan jari telunjuk kanan (saat masih menyeimbangkan). Berdiri lagi dan setelah 2 hitungan yang lain, melompat kembali ke kiri, membungkuk, menyentuh bagian luar pergelangan kaki kiri. Berdiri dan lanjutkan proses ini.

Skor tes adalah berapa kali testi menyentuh pergelangan kaki dalam 30 detik tanpa jatuh. Jika testi jatuh, kembali ke titik awal dan mulai beraksi lagi. Lanjutkan menghitung dimana testi berhenti ketika terjatuh.

Kelima, Bass Stepping-Stone. Gunakan pita untuk menandai lima baris (sejauh $30 \mathrm{~cm}$ ) di atas lantai yang terarah sehingga tegak lurus terhadap garis imajiner sejauh 3 meter. Jarak antar garis yang satu dengan yang lain sejauh 0,75 meter. Seimbangkan pada dada kaki dari satu kaki di atas tanda pertama. Melompat maju ke tanda berikutnya, mendarat di atas dada kaki dari kaki yang lain. Tahan posisi selama 2 hitungan (menghitung dengan suara keras) dan kemudian melompat ke setiap tanda. Lanjutkan melompat ke setiap tanda, putar balik ketika testi sampai ke akhir, tetap pada satu kaki dan berbalik perlahan-lahan dengan melompat dan kembali ke arah lain.

Skor tes adalah jumlah baris yang dilewati dalam 30 detik. Jika testi terjatuh atau gagal untuk menyelesaikan 2 hitungan, pindah ke jalur garis di mana testi terjatuh dan berlanjut sampai waktu berakhir.

Keenam, Book-Balancing Walk. Tempatkan selotip (sepanjang 3 meter) di atas lantai. Dimulai di salah satu ujung dari pita, berjalan dari tumit sampai jari kaki sambil menyeimbangkan sebuah buku di kepala testi. Skor tes adalah jumlah waktu yang digunakan untuk berjalan, berbalik dan kembali tanpa menjatuhkan buku atau melangkah dari garis. Jika testi menjatuhkan buku, tempatkan kembali di kepala testi dan lanjutkan dari titik di mana testi terjatuh.

\section{Teknik Analisis Data}

Teknis analisis data yang digunakan adalah teknik analisis varian (anava) dua jalur pada $\alpha=5 \%$. Jika nilai $F$ yang diperoleh $\left(\mathrm{F}_{\mathrm{O}}\right)$ signifikan analisis dilanjutkan dengan uji Tukey. Untuk memenuhi asumsi dalam teknik anava, maka dilakukan uji normalitas dengan uji Lilliefors dan uji homogenitas varians dengan uji Bartlett.

Urutan langkah-langkah analisis data penelitian ini adalah:
Uji Prasyarat Analisis Data

\section{Uji Normalitas}

Uji normalitas data penelitian ini menggunakan metode Lilliefors. Adapun prosedur pengujian normalitas tersebut adalah sebagai berikut: (1) Pengamatan $\mathrm{x}_{1}, \mathrm{x}_{2}, \ldots \ldots, \mathrm{x}_{\mathrm{n}}$ dijadikan bilangan baku $\mathrm{z}_{1}, \mathrm{z}_{2}, \ldots \ldots$, zn dengan menggunakan rumus:

$$
\mathrm{Zi}=\frac{x i-\bar{x}}{s}
$$

Keterangan:

$\bar{X}=$ Rata-rata

$\mathrm{Xi}=$ Nilai Variabel

$\mathrm{S}=$ Simpangan baku

(2) Untuk setiap bilangan baku ini dan menggunakan daftar distribusi normal baku, kemudian dihitung peluang $\mathrm{F}\left(\mathrm{z}_{\mathrm{i}}\right)=\mathrm{p}\left(\mathrm{z} \leq \mathrm{z}_{\mathrm{i}}\right)$; (3) Selanjutnya dihitung proporsi $z_{1}, z_{2}, \ldots \ldots, z_{n}$ yang lebih kecil atau sama dengan $z_{i}$. Jika proporsi dinyatakan oleh S(zi), maka:

$$
\mathrm{S}(\mathrm{zi})=\frac{\text { banyaknya } z 1, z 2_{\text {namm } z \text { nyang } \leq z 1}}{n}
$$

(4) Hitung selisih $\mathrm{F} \quad\left(\mathrm{z}_{\mathrm{i}}\right)-\mathrm{S}\left(\mathrm{z}_{\mathrm{i}}\right)$, kemudian ditentukan harga mutlaknya; (5) Ambil harga yang paling besar di antara harga-harga mutlak selisih tersebut. Sebutlah harga terbesar ini merupakan Lo.

Untuk menerima atau menolak hipotesis nol, bandingkan Lo ini dengan nilai kritis L yang diambil dari daftar uji Liliefors untuk taraf nyata $\alpha$ yang dipilih. Kriterianya adalah tolak hipotesis nol bahwa populasi bestribusi normal jika Lo yang diperoleh dari data pengamatan melibihi L dari daftar. Dalam hal ini lainnya hipotesis nol diterima (Sudjana, 2002: 466-467).

\section{Uji Homogenitas}

Uji homogenitas dilakukan dengan uji Bartlett, langkah-langkah pengujiannya sebagai berikut: (1) Membuat tabel perhitungan yang terdiri dari kolom-kolom kelompok sampel; dk (n-1); 1/dk; $\mathrm{SD}_{\mathrm{i}}{ }^{2}$, dan (dk) $\log \mathrm{SD}_{\mathrm{i}}{ }^{2} ;$ (2) Menghitung varians gabungan dari semua sampel, dengan rumus:

$\mathrm{SD}^{2}=\frac{(n-1) \mathrm{SDi} 2}{(n-1)}$

$\mathrm{B}=\log \mathrm{SDi}^{2}(\mathrm{n}-1)$

(3) Menghitung $\chi^{2}$, dengan rumus:

$\chi^{2}=(\operatorname{Ln}) \mathrm{B}-(\mathrm{n}-1) \log \mathrm{SD}_{\mathrm{i}} \ldots \ldots$ (2)

dengan $(\operatorname{Ln} 10)=2,3026$. Hasilnya $\left(\chi^{2}\right.$ hitung kemudian dibandingkan dengan $\chi^{2}$ tabel, pada 
taraf signifikansi $\alpha=5 \%$ dan $\mathrm{dk}$ (n-1). Apabila $\chi^{2}{ }_{\text {hitung }}<\chi_{\text {tabel }}^{2}$ maka Ho diterima. Artinya varians sampel bersifat homogen. Sebaliknya

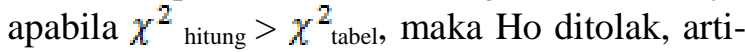
nya varians sampel bersifat tidak homogen (Sudjana, 2002, pp.261-264).

\section{Pengujian Hipotesis}

Langkah-langkah melakukan uji hipotesis adalah sebagai berikut: Anava Rancangan Faktorial 2x2. Metode AB untuk perhitungan Anava Dua Faktor. Ringkasan ANAVA dua faktor dapat dilihat dalam tabel 2. berikut.

Tabel 2.

\begin{tabular}{ccccc}
\hline Sumber Variasi & Dk & Jk & RJK & $\mathbf{F}_{\mathbf{o}}$ \\
\hline Rata-rata & 1 & Ry & R & \\
Perlakuan & & & & \\
A & $\mathrm{a}-1$ & $\mathrm{Ay}$ & $\mathrm{A}$ & $\mathrm{A} / \mathrm{E}$ \\
B & $\mathrm{b}-1$ & $\mathrm{By}$ & $\mathrm{B}$ & $\mathrm{B} / \mathrm{E}$ \\
AB & $(\mathrm{a}-1)(\mathrm{b}-1)$ & $\mathrm{ABy}$ & $\mathrm{AB}$ & $\mathrm{AB} / \mathrm{E}$ \\
Kekeliruan & $\mathrm{ab}(\mathrm{n}-1)$ & $\mathrm{Ey}$ & $\mathrm{E}$ & \\
\hline
\end{tabular}

Keterangan

$\mathrm{A}=$ Kelompok $\mathrm{A}$

$\mathrm{B}=$ Kelompok $\mathrm{B}$

$\mathrm{AB}=$ Interaksi antara kelompok A dengan Kelompok $\mathrm{B}$

$\mathrm{n}=$ Jumlah sampel

Kriteria Pengujian Hipotesis, jika $\mathrm{F} \geq$ $\mathrm{F}(1-\alpha)$ (v1-v2), maka hipotesis nol ditolak. Jika $\mathrm{F}<\mathrm{F}(1-\alpha)$ (v1-v2), maka hipotesis nol diterima. Dengan demikian dk pembilang v1 (k1) dan dk penyebut $\mathrm{v} 2=(\mathrm{n} 1+\ldots \mathrm{nk}-\mathrm{k}), \alpha=$ taraf signifikansi untuk pengujian hipotesis dan dilanjutkan dengan uji Tukey.

\section{Hasil Penelitian dan Pembahasan}

Data keterampilan motorik tersebut, setelah dianalisis kemudian disajikan dalam rangkuman yang berisi harga-harga $\mathrm{n}, \bar{x}, \mathrm{~S}, \sum x_{\text {, }}$ dan $\sum x^{2}$, untuk setiap perlakuan. Rangkuman harga-harga data keterampilan motorik tersebut disajikan dalam tabel 3. berikut.

Rangkuman Hasil Perhitungan HargaHarga $\mathrm{n}, \bar{x}, \mathrm{~S}, \sum x$, dan $\sum x^{2}$ pada data Hasil Penelitian.

Tabel 3

\begin{tabular}{|c|c|c|c|c|}
\hline \multirow{2}{*}{\multicolumn{2}{|c|}{$\begin{array}{c}\text { Kemampuan Perseptual Motorik Sumber } \\
\text { Statistik }\end{array}$}} & \multicolumn{2}{|c|}{ Model Aktivitas } & \multirow[b]{2}{*}{ Jumlah } \\
\hline & & $\begin{array}{c}\text { Bermain dengan } \\
\text { Alat }\end{array}$ & $\begin{array}{c}\text { Bermain tanpa } \\
\text { Alat }\end{array}$ & \\
\hline \multirow{5}{*}{ Tinggi } & $\mathrm{n}$ & 7 & 7 & 14 \\
\hline & $\bar{x}$ & 51,33 & 49,57 & 50,45 \\
\hline & $\mathrm{S}$ & 0,85 & 0,87 & \\
\hline & $\sum x$ & 359,30 & 347,00 & 706,3 \\
\hline & $\sum x^{2}$ & 129099,2 & 120409 & 1349508,2 \\
\hline \multirow{5}{*}{ Rendah } & $\mathrm{n}$ & 7 & 7 & 13 \\
\hline & $\bar{x}$ & 48,47 & 48,43 & 48,45 \\
\hline & $\mathrm{S}$ & 1,20 & 1,27 & \\
\hline & $\sum x$ & 339,29 & 339,00 & 339,145 \\
\hline & $\sum x^{2}$ & 115119.3 & 114921 & 230040,3 \\
\hline \multirow{5}{*}{ Total } & $\mathrm{n}$ & 14 & 14 & 28 \\
\hline & $\bar{x}$ & 99, & 98 & 98,9 \\
\hline & $\mathrm{S}$ & 2,05 & 2,14 & \\
\hline & $\sum x$ & 698,59 & 686 & 1384,59 \\
\hline & $\sum x^{2}$ & 311369,34 & 235330 & 546699,34 \\
\hline
\end{tabular}


$\sum x$ : jumlah skor

$\sum x^{2}:$ jumlah skor dikuadratkan

Untuk keperluan pengujian hipotesis, terlebih dahulu memerlukan beberapa uji persyaratan yaitu: (1) uji normalitas yang dilakukan dengan menggunakan uji Liliefors, dan (2) uji homogenitas dengan menggunakan uji Bartlett.
Uji normalitas dilakukan terhadap data keterampilan motorik pada masing-masing kelompok perlakuan dengan menggunakan uji Liliefors dengan taraf signifikansi $(\alpha) 0,05$. Rangkuman uji normalitas dalam penelitian ini dapat dilihat pada tabel berikut ini. Rangkuman hasil uji normalitas dapat dilihat pada tabel 4 . berikut.

Tabel 4.

\begin{tabular}{ccccc}
\hline Kelompok & $\mathbf{N}$ & $\mathbf{L}_{\mathbf{0}}$ & $\mathbf{L}_{\text {tabel }} \mathbf{\alpha}=\mathbf{0 , 0 5}$ & Kesimpulan \\
\hline $\mathbf{1}$ & 14 & 0,0885 & 0,227 & Normal \\
$\mathbf{2}$ & 14 & 0,0823 & 0,227 & Normal \\
$\mathbf{3}$ & 7 & 0,128 & 0,300 & Normal \\
$\mathbf{4}$ & 7 & 0,1483 & 0,300 & Normal \\
$\mathbf{5}$ & 7 & 0,1042 & 0,300 & Normal \\
$\mathbf{6}$ & 7 & 0,1318 & 0,300 & Normal \\
\hline
\end{tabular}

Keterangan:

Kelompok 1: Kelompok model aktivitas bermain dengan alat secara keseluruhan.

Kelompok 2: Kelompok model aktivitas bermain tanpa alat secara keseluruhan.

Kelompok 3: Kelompok model aktivitas bermain dengan alat pada kemampuan perseptual motorik tinggi.

Kelompok 4: Kelompok model aktivitas bermain dengan alat pada kemampuan perseptual motorik rendah.

Kelompok 5: Kelompok model aktivitas bermain tanpa alat pada kemampuan perseptual tinggi.

Kelompok 6: kelompok model aktivitas bermain tanpa alat pada kemampuan perseptual motorik rendah.

Lo: Harga Liliefors hitung.

Ltabel: Harga Liliefors tabel.

$\mathrm{N}$ : Banyaknya anggota Kelompok.

Berdasarkan tabel tersebut, harga Liliefors hitung untuk seluruh kelompok perlakuan ternyata lebih kecil dibandingkan harga Liliefors tabel. Dengan demikian dapat disimpulkan bahwa sampel diperoleh dari populasi yang berdistribusi normal. Dengan demikian syarat pertama pengujian hipotesis terpenuhi.
Uji homogenitas

Uji homogenitas varians dari data keterampilan motorik untuk masing-masing kelompok perlakuan dilakukan dengan menggunakan uji Bartlett dengan taraf signifikansi $(\alpha) 0,05$. Rangkuman uji homogenitas dapat dilihat pada tabel 4. berikut.

Tabel 4.

\begin{tabular}{cccccc}
\hline Kelompok & Varians & Varians gabungan & $\boldsymbol{X}_{\text {hitung }}^{2}$ & $\begin{array}{c}\boldsymbol{X}_{\text {tabel }}^{2} \\
\boldsymbol{\alpha}=\mathbf{0 , 0 5}\end{array}$ & Kesimpulan \\
\hline $\mathbf{1}$ & 0,4225 & & & & \\
$\mathbf{2}$ & 0,4569 & 0,9706 & $-0,6655$ & 7,81 & Homogen \\
$\mathbf{3}$ & 1,44 & & & & \\
$\mathbf{4}$ & 1,6129 & & & & \\
\hline
\end{tabular}

Keterangan:

Kelompok 1: Kelompok model aktivitas bermain dengan alat pada kemampuan perseptual motorik tinggi.

Kelompok 2: Kelompok model aktivitas bermain dengan alat pada kemampuan perseptual motorik rendah.

Kelompok 3: Kelompok model aktivitas bermain tanpa alat pada kemampuan perseptual tinggi.

Kelompok 4: kelompok model aktivitas bermain tanpa alat pada kemampuan perseptual motorik rendah.

Berdasarkan hasil perhitungan seperti pada tabel di atas, dapat dilihat bahwa $\chi^{2}$ hitung sebesar -0,6655 untuk seluruh kelompok sampel lebih kecil dibandingkan dengan harga $\chi_{\text {tabel }}^{2}$ sebesar 7,81 pada taraf signifikansi $(\alpha)$ 0,05 . Dengan demikian dapat disimpulkan bahwa populasi mempunyai varians yang sama besar atau homogen. Perhitungan lengkap dapat dilihat pada lampiran 7 halaman 130. Uji homogenitas juga dilakukan terhadap varians dua kelompok secara keseluruhan yaitu kelompok kemampuan perseptual motorik (tinggi dan rendah) dan kelompok model aktivitas (bermain dengan alat dan bermain tanpa alat). Pengujian dilakukan dengan cara membandingkan varians 
terbesar dengan varians terkecil dari masinmasing kelompok. Rangkuman perhitungan kesamaan dua varians dapat dilihat pada tabel 5 . berikut.

Tabel 5

\begin{tabular}{|c|c|c|c|c|}
\hline Kelompok & Varians & $F_{0}$ & $\begin{array}{c}\text { Harga } F \text { tabel } \\
\alpha=0,05\end{array}$ & Kesimpulan \\
\hline$A_{1} \operatorname{dan} A_{2}$ & $\begin{array}{l}0,4225 \\
0,4569\end{array}$ & 1,0812 & 2,51 & Homogen \\
\hline$B_{1}$ dan $B_{2}$ & $\begin{array}{c}1,44 \\
1,6129\end{array}$ & 1,1201 & 2,51 & Homogen \\
\hline
\end{tabular}

Keterangan:

$\mathrm{A}_{1}$ : Kelompok model aktivitas bermain dengan alat

$\mathrm{A}_{2}$ : Kelompok model aktivitas bermain tanpa alat

$\mathrm{B}_{1}$ : Kelompok kemampuan perseptual motorik tinggi

$\mathrm{B}_{2}$ : Kelompok kemampuan perseptual motorik rendah

Berdasarkan hasil perhitungan seperti dirangkum pada tabel tersebut, diperoleh harga $F_{o}$ sebesar 1,0812 dan 1,1201 yang lebih kecil bila dibandingkan dengan $\mathrm{F}_{\mathrm{t}}$ sebesar 2,51 pada taraf signifikansi 0,05. Dengan demikian populasi mempunyai kesamaan atau homogen.

Berdasarkan hasil pengujian normalitas dan pengujian homogenitas, maka persyaratan untuk melakukan pengujian hipotesis telah terpenuhi yaitu data penelitian tersebut berdistribusi normal dan homogen.

\section{Pengujian Hipotesis}

Dengan terujinya normalitas dan homogenitas data hasil penelitian, maka syarat untuk keperluan analisis data telah terpenuhi. Selanjutnya pengujian hipotesis dilakukan dengan analisis varians (ANAVA) dua jalur, dan jika terdapat interaksi, akan dilanjutkan dengan uji lanjut Tukey.

Pengujian hipotesis yang dilakukan dengan teknik ANAVA, dengan rangkuman perhitungan sebagaimana pada tabel 6 . berikut.

Tabel 6

\begin{tabular}{cccccc}
\hline Sumber Statistik & Dk & JK & KT & $\mathbf{F}_{\mathbf{0}}$ & $\mathbf{F}_{\mathbf{t}}$ \\
\hline Rata-rata Perlakuan: & 1 & 68468,08 & & & \\
A & 1 & 5,67 & 5,67 & $5.02^{*}$ & 4.26 \\
B & 1 & 28,02 & 28,02 & $5.44^{*}$ & \\
AB & 1 & 5,15 & 5,15 & $4.57^{*}$ & \\
Kekeliruan & 22 & 27,09 & 1,13 & & \\
& & & & & \\
Jumlah & 26 & 68534,01 &
\end{tabular}

Keterangan:

JK: Jumlah Kuadrat

Dk: Derajat Kebebasan

KT: Kuadrat Tengah (rata-rata kuadrat)

$F_{0}$ : Harga $F$ hitung

$F_{t}$ : Harga $F$ tabel

$*$ : signifikan pada taraf nyata $\alpha=0,05$

Berdasarkan rangkuman hasil perhitungan analisis varians tersebut dapat dijelaskan sebagai berikut: (1) Perbedaan pengaruh model aktivitas bermain dengan alat dan aktivitas bermain tanpa alat terhadap keterampilan motorik. Hasil perhitungan analisis varians tentang perbedaan pengaruh model aktivitas bermain dengan alat dibandingkan dengan model aktivitas bermain tanpa alat terhadap keterampilan motorik secara keseluruhan sebagaimana terlihat pada tabel tersebut, bahwa harga $\mathrm{F}$ hitung antar kolom $\mathrm{A} B=5,02$ ternyata lebih besar dari $\mathrm{F}$ tabel dengan $\mathrm{dk}$ pembilang V1 (a1) $(\mathrm{b}-1)=1$, dk penyebut $\mathrm{V} 2 \mathrm{ab}(\mathrm{n}-1)=2 \times 2(7-1)$ $=24$ yaitu sebesar 4,26. Dengan demikian Ho yaitu tidak ada perbedaan pengaruh model aktivitas bermain dengan alat dan aktivitas bermain tanpa alat terhadap keterampilan motorik ditolak, sehingga dapat disimpulkan bahwa secara keseluruhan terdapat perbedaan nyata antara model aktivitas bermain dengan alat dan aktivitas bermain tanpa alat terhadap 
keterampilan motorik. Dengan kata lain model aktivitas bermain dengan alat $(\bar{x}=49,90, \mathrm{~s}=$ 1,79) memberikan pengaruh yag berbeda terhaap keterampilan motorik dibandingkan model aktivitas bermain tanpa alat $(\bar{x}=49,00, \mathrm{~s}$ $=1,20)$. dengan demikian hipotesis penelitian yang menyatakan bahwa secara keseluruhan terdapat perbedaan pengaruh antara model aktivitas dengan alat dan model aktivitas bermain tanpa alat terhadap keterampilan motorik telah teruji dan dilanjutkan dengan uji Tukey.

Dilihat dari data penelitian secara keseluruhan diperoleh harga rata-rata keterampilan motorik yang menggunakan model aktivitas bermain dengan alat sebesar $\bar{x}=49,90$ dengan simpangan baku sebesar $\mathrm{s}=1,79$ dan harga rata-rata keterampilan motorik model aktivitas bermain tanpa alat sebesar $\bar{x}=49,00$ dengan simpangan baku sebesar $\mathrm{s}=1,20$, dapat diartikan bahwa hipotesis penelitian yang menyatakan bahwa secara keseluruhan model aktivitas bermain dengan alat lebih tinggi dibandingkan dengan model aktivitas bermain tanpa alat terhadap keterampilan motorik menjadi teruji.

Berdasarkan hasil uji lanjut dengan menggunakan uji Tukey diperoleh harga $\mathrm{q}$ hitung sebesar 3,21 yang lebih besar dari q tabel dengan taraf signifikansi $\alpha=0,05$ dan $\mathrm{dk} 2 / 28$ sebesar 2,89 sehingga Ho yaitu tidak terdapat perbedaan pengaruh model aktivitas bermain dengan alat dan aktivitas bermain tanpa alat terhadap keterampilan motorik ditolak. Dengan demikian dapat disimpulkan bahwa terdapat perbedaan yang signifikan model aktivitas bermain dengan alat memiliki pengaruh yang lebih tinggi dibandingkan dengan aktivitas bermain tanpa alat terhadap keterampilan motorik; (2) Perbedaan pengaruh model aktivitas bermain dengan alat pada kelompok kemampuan perseptual motorik tinggi (A1B1) dan model aktivitas bermain tanpa alat pada kelompok kemampuan perseptual motorik tinggi (A2B1) terhadap keterampilan motorik.

Dari data penelitian dapat dilihat bahwa rata-rata skor keterampilan motorik yang menggunakan model aktivitas bermain dengan alat pada kelompok dengan kemampuan perseptual motorik tinggi adalah sebesar $\bar{x}=51,33$ dengan simpangan baku sebesar $\mathrm{s}=0,85$ sedangkan rata-rata skor keterampilan motorik yang menggunakan model aktivitas bermain tanpa alat pada kelompok kemampuan perseptual motorik tinggi adalah sebesar $\bar{x}=49,57$ dengan simpangan baku sebesar $\mathrm{s}=0,87$.
Dengan demikian Ho yaitu tidak terdapat perbedaan pengaruh model aktivitas bermain dengan alat pada kelompok kemampuan perseptual motorik tinggi dan model aktivitas bermain tanpa alat pada kelompok kemampuan perseptual motorik tinggi terhadap keterampilan motorik ditolak, dan hipotesis yang menyatakan bahwa model aktivitas bermain dengan alat pada kelompok kemampuan perseptual motorik tinggi lebih baik dibandingkan dengan model aktivitas bermain tanpa alat pada kelompok perseptual motorik tinggi telah teruji kebenarannya.

Hasil uji lanjut antara model aktivitas bermain dengan alat pada kelompok kemampuan perseptual motorik tinggi (A1B1) dibandingkan dengan model aktivitas bermain tanpa alat terhadap keterampilan motorik pada kelompok kemampuan perseptual motorik tinggi (A2B1), diperoleh q hitung sebesar 6,29 yang lebih besar dari q tabel dengan taraf signifikansi $\alpha=$ 0,05 dengan $\mathrm{dk}=4 / 28$ yaitu sebesar 3,85 . Dengan demikian Ho yaitu tidak terdapat perbedaan pengaruh model aktivitas bermain dengan alat pada kelompok kemampuan perseptual motorik tinggi dan model aktivitas bermain tanpa alat pada kelompok kemampuan perseptual motorik tinggi terhadap keterampilan motorik ditolak, sehingga dapat disimpulkan bahwa terdapat perbedaan antara model aktivitas bermain dengan alat dan model aktivitas bermain tanpa alat terhadap keterampilan motorik pada kelompok dengan kemampuan perseptual motorik tinggi; (3) Perbedaan pengaruh model aktivitas bermain dengan alat pada kelompok dengan kemampuan perseptual motorik rendah $\left(\mathrm{A}_{1} \mathrm{~B}_{2}\right)$ dan model aktivitas bermain tanpa alat pada kelompok dengan kemampuan perseptual motorik rendah $\left(\mathrm{A}_{2} \mathrm{~B}_{2}\right)$ terhadap keterampilan motorik.

Dari data penelitian mengenai keterampilan motorik yang menggunakan model aktivitas bermain dengan alat pada kelompok dengan kemampuan perseptual motorik rendah diperoleh skor rata-rata sebesar $\bar{x}=48,47$ dengan simpangan baku sebesar $\mathrm{s}=1,20$, sedangkan rata-rata skor keterampilan motorik yang menggunakan model aktivitas bermain tanpa alat pada kelompok dengan kemampuan perseptual motorik rendah diperoleh sebesar $\bar{x}=48.43$ dengan simpangan baku sebesar $\mathrm{s}=1,27$. Berdasarkan kedua rata-rata tersebut, maka Ho yaitu tidak terdapat perbedaan pengaruh model aktivitas bermain dengan alat pada kelompok dengan kemampuan perseptual motorik rendah dan model aktivitas bermain tanpa alat pada ke- 
lompok dengan kemampuan perseptual motorik rendah terhadap keterampilan motorik gagal ditolak. Dengan demikian hipotesis penelitian yang menyatakan bahwa model aktivitas bermain dengan alat lebih baik dari model aktivitas bermain tanpa alat pada kelompok dengan kemampuan peseptual motorik rendah tidak terbukti.

Hasil uji lanjut antara model aktivitas bermain dengan alat pada kelompok dengan kemampuan perseptual motorik rendah $\left(\mathrm{A}_{1} \mathrm{~B}_{2}\right)$ dengan model aktivitas bermain tanpa alat pada kelompok dengan kemampuan perseptual motorik rendah $\left(\mathrm{A}_{2} \mathrm{~B}_{2}\right)$, diperoleh $\mathrm{q}$ hitung sebesar 0,14 yang lebih kecil dari q tabel dengan taraf signifikansi $\alpha=0,05$ dah $d k$ 4/28 yaitu sebesar 3,85 . Dengan demikian Ho yaitu tidak terdapat perbedaan pengaruh model aktivitas bermain dengan alat pada kelompok dengan kemampuan perseptual motorik rendah dan model aktivitas bermain tanpa alat pada kelompok dengan kemampuan perseptual motorik rendah terhadap keterampilan motorik gagal ditolak, dan dapat disimpulkan bahwa tidak terdapat perbedaan pengaruh terhadap keterampilan motorik, baik menggunakan model aktivitas bermain dengan alat maupun model aktivitas bermain tanpa alat pada kelompok dengan kemampuan perseptual motorik rendah; (4) Interaksi aktivitas bermain dan kemampuan perseptual motorik terhadap keterampilan motorik siswa sekolah dasar kelas bawah.

Berdasarkan hasil analisis Varians (ANAVA) dua jalan dengan taraf signifikansi $\alpha$ $=0,05$ iperoleh hasil perhitungan Fo interaksi $\left(\mathrm{F}_{\mathrm{AB}}\right)$ sebesar 4,57 yang lebih besar dari $\mathrm{F}$ tabel yaitu sebesar 4,26 sehingga Ho yaitu tidak terdapat interaksi aktivitas bermain dan kemampuan perseptual motorik terhadap keterampilan motorik siswa sekolah dasar kelas bawah ditolak. Dengan demikian dapat disimpulkan terdapat interaksi antara model aktivitas dengan kemampuan perseptual motorik terhadap keterampilan motorik, dan telah teruji secara empiris.

Dari data hasil penelitian dapat dilihat bahwa skor rata-rata keterampilan motorik yang menggunakan model aktivitas bermain dengan alat adalah sebesar 51,33 untuk kelompok kemampuan perseptual motorik tinggi dan 48,47 untuk kelompok dengan kemampuan perseptual motorik rendah. Kemudian skor rata-rata keterampilan motorik yang menggunakan model aktivitas bermain tanpa alat adalah sebesar 49,57 untuk kelompok dengan kemampuan perseptual motorik tinggi dan 48,43 untuk ke- lompok dengan kemampuan perseptual motorik rendah. Dengan demikian dapat disimpulkan bahwa terjadi interaksi antara model aktivitas bermain dan kemampuan perseptual motorik terhadap keterampilan motorik. Interaksi yang lebih baik dari eksperimen yang telah dilakukan adalah interaksi antara aktivitas bermain dengan alat dan kemampuan perseptual motorik tinggi karena berdasarkan hasil penelitian aktivitas bermain dengan alat dan kemampuan perseptual motorik tinggi memberikan kontribusi positif terhadap keterampilan motorik anak. Interaksi tersebut dapat terlihat pada gambar 9. berikut.

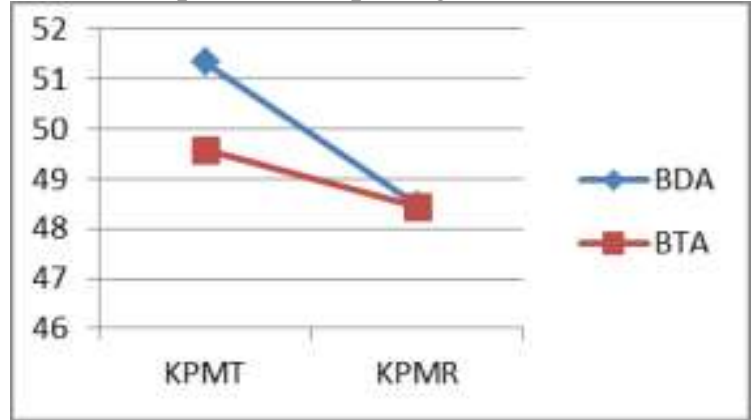

Keterangan:

BDA: Aktivitas bermain dengan alat

BTA: Aktivitas bermain tanpa alat

KMPT: Kemampuan perseptual motorik tinggi

KPMR: Kemampuan perseptual motorik rendah

Hasil penelitian hipotesis pertama menunjukkan bahwa terdapat perbedaan keterampilan motorik yang signifikan sebagai pengaruh model aktivitas bermain dengan alat dan model aktivitas bermain tanpa alat. Secara keseluruhan keterampilan motorik yang menggunakan model aktivitas bermain dengan alat lebih tinggi dibandingkan dengan menggunakan model aktivitas bermain tanpa alat. Aktivitas bermain merupakan cara yang tepat dalam memberikan materi pembelajaran penjas khususnya di usia sekolah dasar kelas bawah. Melalui bermain anak-anak akan merasa senang karena salah satu ciri dari permainan yaitu adanya rasa senang yang dapat membuat anak mengikuti proses pembelajaran secara sukarela tanpa adanya paksaan dan proses pembelajaran akan berjalan efektif dan efisien.

Hasil analisis tersebut sesuai dengan teori bahwa aktivitas bermain dengan alat diarahkan untuk meningkatkan keterampilan motorik dalam proses pembelajaran penjas di sekolah. Model aktivitas bermain dengan alat telah terbukti dapat digunakan untuk meningkatkan keterampilan motorik khususnya pengembangan pola gerak dasar yang baik di samping juga pengembangan penalaran yang 
memungkinkan keterampilan dicapai dengan memenuhi empat ranah dalam konsep belajar yaitu kognitif, afektif, psikomotor, dan sosial. Kondisi tersebut dapat tercapai adanya transfer belajar di mana anak berhasil menguasai komponen keterampilan motorik melalui model aktivitas bermain yang memungkinkan anak memahami jenis-jenis permainan, memahami taktik bermain, dan menguasai keterampilan gerak dasar baik lokomotor, non lokomotor dan manipulatif.

Selanjutnya hasil pengujian hipotesis kedua menyimpulkan bahwa terdapat perbedaan keterampilan motorik pada kelompok dengan kemampuan perseptual motorik tinggi yang menggunakan model aktivitas bermain dengan alat dan menggunakan model aktivitas bermain tanpa alat. Kemampuan perseptual motorik yang dibangun oleh komponen-komponen pemahaman tubuh, pemahaman ruang, kualitas gerak, pemahaman arah, dan hubungan dengan objek diluar tubuh yang baik menjadikan anak memiliki gerak dasar yang baik, mampu melakukan manuver gerak dalam berbagai posisi, dapat mengatasi rintangan saat bergerak, dan memiliki koordinasi gerak serta keseimbangan yang baik pula. Dengan digunakannya model aktivitas bermain dengan alat dalam pembelajaran penjas, anak dengan kemampuan perseptual motorik tinggi telah terbukti mempunyai keterampilan motorik lebih baik.

Hasil pengujian hipotesis ketiga menunjukkan bahwa tidak terdapat perbedaan keterampilan motorik pada kelompok dengan kemampuan perseptual kemampuan motorik rendah baik yang menggunakan model aktivitas bermain dengan alat maupun yang menggunakan model aktivitas bermain tanpa alat. Dengan demikian dapat disimpulkan bahwa kedua model aktivitas bermain dengan alat dan model aktivitas bermain tanpa alat tidak memberikan pengaruh yang signifikan terhadap perbedaan keterampilan motorik pada kelompok kemampuan perseptual motorik rendah.

Beberapa hal yang diduga menyebabkan tidak terujinya hipotesis ketiga antara lain sebagai berikut: (1) program pembelajaran yang diberikan kepada kelompok dengan perseptual motorik rendah baik dengan model aktivitas bermain dengann alat maupun tanpa alat relatif tidak sebanding sehingga dalam proses pembelajaran salah satu kelompok mendapat intensitas pembelajaran yang berbeda sehingga memberikan hasil yang berbeda pula, (2) adanya perbedaan karakteristik sampel di luar usia dan kemampuan perseptual motorik yang tidak dikendalikan sehingga mempengaruhi proses pembelajaran yang berakibat pada adanya perbedaan perlakuan yang diterima anak yang seharusnya sama, (3) keterbatasan alat ukur yang digunakan untuk mengukur hasil penelitian. Penggunaan skala lajuan dengan cara checklist kemungkinan untuk melakukan kesalahan karena berdasarkan pengamatan yang dilakukan oleh manusia yang mempunyai keterbatasan dalam ketelitian dan kewaspadaan.

Pengujian hipotesis melalui ANAVA juga menemukan bahwa terdapat pengaruh model aktivitas bermain dengan kemampuan perseptual motorik terhadap keterampilan motorik sehingga Ho ditolak. Pengaruh interaksi keduanya terlihat dari adanya perbedaan keterampilan pada kedua tingkat kemampuan perseptual motorik. Dengan demikian dapat dikatakan bahwa penggunaan model aktivitas bermain tergantung pada kemampuan perseptual motorik. Model aktivitas bermain dengan alat lebih efektif untuk anak dengan kemampuan perseptual motorik tinggi, sedangkan untuk kemampuan perseptual rendah kedua model pembelajaran memberikan pengaruh yang tidak berbeda terhadap keterampilan motorik pada siswa sekolah dasar kelas bawah.

\section{Simpulan dan Saran}

Simpulan

Berdasarkan hasil penelitian dan pengujian hipotesis dapat ditarik suatu kesimpulan sebagai berikut: (1) secara keseluruhan keterampilan motorik siswa sekolah dasar kelas bawah yang menggunakan model aktivitas bermain dengan alat lebih tinggi dibandingkan keterampilan motorik siswa sekolah dasar kelas bawah yang menggunakan model aktivitas bermain tanpa alat, (2) keterampilan motorik siswa sekolah dasar kelas bawah pada kelompok kemampuan perseptual motorik tinggi yang menggunakan model aktivitas bermain dengan alat lebih tinggi dibandingkan keterampilan motorik siswa sekolah dasar kelas bawah pada kelompok kemampuan perseptual motorik tinggi yang menggunakan model aktivitas bermain tanpa alat, (3) keterampilan motorik siswa sekolah dasar kelas bawah pada kelompok kemampuan perseptual motorik rendah yang menggunakan model aktivitas bermain dengan alat tidak berbeda secara signifikan dibandingkan dengan keterampilan motorik siswa sekolah dasar kelas bawah yang menggunakan model 
aktivitas bermain tanpa alat, (4) terdapat pengaruh interaksi antara model aktivitas bermain dan kemampuan perseptual motorik terhadap keterampilan motorik siswa sekolah dasar kelas bawah, (5) interaksi antara aktivitas bermain dengan alat dan kemampuan perseptual motorik merupakan interaksi yang paling baik dalam mengembangkan keterampilan motorik siswa sekolah dasar kelas bawah.

Saran

Berdasarkan hasil penelitian yang telah dilakukan, terbukti bahwa model aktivitas bermain dengan alat lebih efektif digunakan pada anak dengan kemampuan perseptual motorik tinggi terutama untuk pembelajaran penjas di kelas 1, 2 dan 3 sekolah dasar. Kepada guru penjas disarankan agar menggunakan modelmodel permainan dengan alat sebagai salah satu alternatif dalam proses pembelajaran.

Model aktivitas bermain dengan alat hanyalah salah satu model pembelajaran dari sekian banyak model pembelajaran dengan berbagai pendekatan, penggunaannya sangat tergantung pada karakteristik anak dan jenis pelajaran yang diberikan. Oleh karena itu tidak ada satupun model pembelajaran yang paling baik yang dapat digunakan untuk mencapai tujuan pembelajaran. Dengan mengkombinasikan beberapa model pembelajaran yang disesuaikan dengan kebutuhan anak, kiranya merupakan jalan keluar terbaik untuk memecahkan masalah-masalah pembelajaran, khususnya pembelajaran penjas pada kelas 1,2 dan 3 sekolah dasar.

\section{Daftar Pustaka}

Arikunto, Suharsimi. 2007. Manajemen penelitian. Jakarta: PT RinekaCipta

Bullus J., Colles P. (2007). Smart Start with P.M.P a Perceptual Motor Program. 4th edition. Victoria Australia: Smart Startes.

Drowatsky \& Zuccato. (1967). Diambil pada tanggal 10 November 2012 dari http://hk.humankinetics.com/Biomecha nicsOfMusculoskeletalInjury/pdf/lab6_ 1.pdf.

Hartoto. (2009). Definisi Pendidikan. Diambil pada tanggal 3 November 2012 dari http://fatamorghana.wordpress.com/200 9/11/02/definisi-pendidikan/.

Lutan, Rusli. (2001). Asas-asas pendidikan jasmani. Jakarta: Direktorat Jenderal Olahraga, Depdiknas.

Miller, K.D. (2000). Measurement by the physical educator why and how. New York: McGraw-Hill.

Qomariyah, Nurul. (2009). Keterampilan motorik dan sikap. Diambil pada tanggal 15 November 2012 dari http://alyaqanitha.wordpress.com/2009/ 02/08/ketrampilan-motorik-dan-sikap/.

Sudjana. (2002). Desain dan analisis eksperimen. Bandung: Tarsito. 